\title{
Article/Artigo
}

\section{Ultrasound and magnetic resonance imaging findings in Schistosomiasis mansoni: expanded gallbladder fossa and fatty hilum signs}

\author{
Achados da ultrassonografia e da ressonância magnética na esquistossomose mansônica: \\ sinais da expansão da fossa da vesícula e do hilo gorduroso
}

\author{
Luciana Cristina dos Santos Silva ${ }^{1}$, Luciene Mota Andrade ${ }^{1,2}$, Ivie Braga de Paula ${ }^{2}$, Leonardo Campos de Queiroz ${ }^{3}$, \\ Carlos Maurício Figueiredo Antunes ${ }^{1}$ and José Roberto Lambertucci ${ }^{1}$
}

\section{ABSTRACT}

Introduction: There is no study relating magnetic resonance imaging (MRI) to ultrasound (US) findings in patients with Schistosomiasis mansoni. Our aim was to describe MRI findings in patients with schistosomal liver disease identified by US. Methods: Fifty-four patients (mean age 41.6 \pm 13.5 years) from an area endemic for Schistosomiasis mansoni were selected for this study. All had US indicating liver schistosomal fibrosis and were evaluated with MRI performed with a 1.5-T superconducting magnet unit (Sigma). Results: Forty-seven (87\%) of the 54 patients showing signs of periportal fibrosis identified through US investigation had confirmed diagnoses by MRI. In the seven discordant cases (13\%), MRI revealed fat tissue filling in the hilar periportal space where US indicated isolated thickening around the main portal vein at its point of entry to the liver. We named this the fatty hilum sign. One of the 47 patients with MRI evidence of periportal fibrosis had had his gallbladder removed previously. Thirty-five $(76.1 \%)$ of the other 46 patients had an expanded gallbladder fossa filled with fat tissue, whereas MRI of the remaining eleven showed pericholecystic signs of fibrosis. Conclusions: Echogenic thickening of the gallbladder wall and of the main portal vein wall heretofore attributed to fibrosis were frequently identified as fat tissue in MRI. However, the gallbladder wall thickening shown in US (expanded gallbladder fossa in MRI) is probably secondary to combined hepatic morphologic changes in schistosomiasis, representing severe liver involvement.

Keywords: Schistosomiasis. Magnetic resonance imaging. Ultrasound. Hepatic fibrosis. Gallbladder fossa.

\section{RESUMO}

Introdução: Não existem estudos que correlacionam os achados da ressonância magnética (RM) aos da ultrassonografia (US) em pacientes com esquistossomose mansônica. O objetivo deste estudo foi descrever os achados da imagem por RM em pacientes com doença hepática esquistossomótica identificada por US. Métodos: Selecionaram-se 54 pacientes com idade

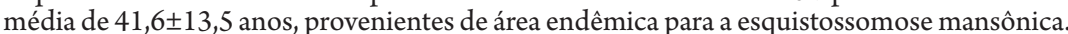
Todos apresentavam US indicativa de fibrose hepática esquistossomótica, e foram avaliados com imagens por RM, realizadas com uma unidade magnética supercondutora de 1,5-T (Sigma). Resultados: Quarenta e sete (87\%) entre 54 pacientes com sinais ultrassonográficos de fibrose periportal esquistossomótica tiveram este diagnóstico confirmado pela RM. Nos sete (13\%) casos discordantes, a RM revelou tecido adiposo preenchendo o espaço periportal hilar onde a US indicava espessamento isolado da parede da veia porta em seu ponto de entrada no fígado. Este achado foi nomeado sinal do hilo gorduroso. Um dos 47 pacientes com evidência de fibrose periportal RM era colecistectomizado. Trinta e quatro $(76,1 \%)$ dos 46 pacientes restantes apresentavam expansão da fossa da vesícula, que se encontrava preenchida por tecido adiposo. Nos outros sete, a RM revelou sinais de fibrose pericolecística. Conclusões: Os espessamentos ecogênicos central da parede da veia porta, e da parede da vesícula biliar, até o momento, atribuídos à fibrose, foram frequentemente identificados como tecido adiposo pela RM. Entretanto, o espessamento da parede da vesícula identificado pela US (expansão da fossa da vesícula na RM) é provavelmente secundário a alterações morfológicas hepáticas na esquistossomose, e representa comprometimento grave do fígado.

Palavras-chaves: Esquistossomoses. Ressonância magnética. Ultrassonografia. Fibrose hepática. Fossa da vesícula.

1. Programa de Pós-Graduação em Ciências da Saúde Infectologia e Medicina Tropical, Faculdade de Medicina, Universidade Federal de Minas Gerais, Belo Horizonte, MG. 2. Departamento de Diagnóstico por Imagem, Instituto Hermes Pardini, Belo Horizonte, MG. 3. Divisão de Radiologia, Hospital das Clínicas, Universidade Federal de Minas Gerais, Belo Horizonte, MG.

Address to: Dra. Luciana Cristina dos Santos Silva. FM/UFMG. Av. Alfredo Balena 190, sala 169, 30130100 Belo Horizonte, MG, Brazil.

Phone/Fax: 5531 3409-9820

e-mail: lucristina@medicina.ufmg.br

Received in 30/07/2011

Accepted in 30/09/2011

\section{INTRODUCTION}

Schistosomiasis affects 200 million people worldwide. Manson's schistosomiasis causes periportal fibrosis (or Symmers' white clay pipestem fibrosis) and portal hypertension in about $10 \%$ of infected subjects, usually with preservation of the hepatic function ${ }^{1,2}$. The assessment of liver involvement is of major importance in determining prognosis and risk of complications from schistosomiasis such as upper digestive bleeding secondary to variceal rupture. The goldstandard procedure in evaluating schistosomal hepatic fibrosis has been wedge liver biopsy. This is an invasive procedure that is safe during abdominal surgery but not justified in nonsurgical patients. An alternative procedure - percutaneous liver biopsywas not validated for schistosomiasis. This method has not been evaluated in schistosomal liver disease lately, and former studies suggested low sensitivity ${ }^{3-5}$.

For the last two decades, abdominal ultrasound (US) has become the best imaging technique to evaluate liver fibrosis due to Schistosomiasis mansoni $i^{6,7}$. It is an indirect method for diagnosing and classifying the disease ${ }^{8-16}$. Ultrasonographic examination of subjects with hepatosplenic schistosomiasis has detected a characteristic pattern of abnormalities, quite different from the aspects observed in liver cirrhosis ${ }^{10,11}$ and in acute schistosomiasis ${ }^{17,18}$. The most important findings are echogenic thickening of the walls of the portal vein and its branches, indicative of periportal fibrosis, and echogenic enlargement of the gallbladder wall. However, US is a subjective procedure and, thus, examiner dependent, even if the World Health Organization (WHO) protocol for US assessment of schistosomiasis is applied ${ }^{14}$.

Magnetic resonance imaging (MRI), different from US, is less examiner dependent. MRI findings have previously been described in hepatosplenic Schistosomiasis mansoni ${ }^{19-26}$, but in the series of cases published, the authors established no major 
disagreement to what has been reported in ultrasound findings. The purpose of this study is to describe MRI findings in patients with US-identified schistosomal liver disease, with a special focus on the points in which the two methods differ.

\section{METHODS}

\section{Subjects}

Fifty-four patients with routinely performed US diagnosis of liver involvement in schistosomiasis attending a University Reference Center for Infectious Diseases were studied from 2004 to 2006. Diagnosis of schistosomiasis was established through characteristic US signs of periportal fibrosis in a patient exposed to stream waters of an endemic area. Patients included in the study had no history of previous surgery for portal hypertension or evidence of other causes of chronic liver disease, such as cirrhosis, congestive heart failure, and toxic or viral hepatitis.

\section{Methods}

Study evaluation included clinical history and physical examination, blood cell count, serum albumin, prothrombin time, aspartate aminotransferase, alanine aminotransferase, and serology tests for hepatitis B and C. Serological tests for S. mansoni were not performed. Ultrasound was repeated following the WHO protocol. Upper digestive endoscopy was performed as clinically indicated.

Ultrasonographic examination of the abdomen was performed using real-time equipment (Aloka SSD 1700, Aloka Co., Japan) with an electronic convex $3.5-\mathrm{MHz}$ transducer, according to the $\mathrm{WHO}$ protocol for US assessment of schistosomiasis-related morbidity ${ }^{14}$ by a radiologist who has had eight years' experience in this imaging method. The thicknesses of the gallbladder wall, the hepatic hilum portal vein wall at the entry point to the liver, and its bifurcation and secondary branches were gauged. Measurements for the secondary branches of the portal vein were taken at the point where the walls were thickest but, otherwise, as close as possible to the first branching point where the segmental branch leaves the major left or right portal branch. The following reference values were considered: thickness of the gallbladder wall, $4 \mathrm{~mm}$; thickness of the hepatic hilum portal vein wall, $8 \mathrm{~mm}$; and thickness of the secondary portal branch walls, $3 \mathrm{~mm}$. Ultrasound confirmed periportal thickening as a sign of hepatic involvement in schistosomiasis in all 54 patients.

Magnetic resonance imaging was performed using a $1.5-\mathrm{T}$ superconducting magnet unit (Sigma; GE Medical Systems, Milwaukee, Wis, USA) having an eight-element torso phasedarray coil (GE Medical Systems). MRI studies were as follows: A) Axial T1-weighted in-phase and out-of-phase breath-hold spoiled gradient-echo MRI was performed with repetition time/echo time, $90-200 \mathrm{msec} / 2.1 \mathrm{msec}$ (out-of-phase), $4.2 \mathrm{msec}$ (in-phase); flip angle, $70^{\circ}-90^{\circ}$; section thickness, $8 \mathrm{~mm}$; intersection gap, $1 \mathrm{~mm}$; matrix, 256 × 128-192; field of view, $32-40 \mathrm{~cm}$; and one signal acquired. Dual-echo acquisition was used in all patients. B) Axial and coronal T2-weighted single-shot fast spin-echo MRI with and without fat saturation, non-breath-hold respiratory triggered, was performed with repetition time/echo time, 1,800/90 (effective); section thickness, $7 \mathrm{~mm}$; intersection gap, 1mm; matrix, $256 \times 192-224$; field of view, $32-40 \mathrm{~cm}$; and one signal acquired. Fat saturation was applied by using manual frequency selection. C) Axial fast imaging using steady-state acquisition (3D FIESTA; GE Medical Systems) was obtained with repetition time/echo time, 3.7/1.6; flip angle, $45^{\circ}$; section thickness, $7 \mathrm{~mm}$; intersection gap, $1 \mathrm{~mm}$; matrix, $320 \times 256$; field of view, $40 \mathrm{~cm}$; and one signal acquired. D) Patients were imaged using a transverse volumetric three-dimensional fat-suppressed spoiled gradient-echo acquisition dynamic called LAVA (liver acquisition with volume acceleration; GE Medical Systems), breath-hold, and the method was performed following the parameters: repetition time/echo time, $4.5 / 2.2,12^{\circ}$ flip angle; section thickness ranging from 160 to $200 \mathrm{~mm}$ to ensure full coverage of the liver; preinterpolation partition thickness and matrix, $3.6 \mathrm{~mm}$ and $320 \times 224$, respectively. Interpolation in the section-select direction yielded a partition thickness of $1.8 \mathrm{~mm}$. In all the patients, this sequence was performed without contrast material and was followed by an acquisition timed according to data from a test bolus of $0.1 \mathrm{mmol} / \mathrm{kg}$ dose of gadopentetate dimeglumine (Magnevist; Bayer-Shering Pharma, Germany), using the circulation time as the first acquisition (hepatic arterial phase) delay time. This acquisition was then repeated twice at 45 -second intervals for portal venous and equilibrium phase contrast material-enhanced MRI.

Magnetic resonance imaging analysis was conducted by two different radiologists with ten and three years of prior experience, respectively. Examinations were conducted using an adapted version of the WHO protocol proposed for US assessment of schistosomiasisrelated morbidity ${ }^{14}$. The gallbladder fossa was considered expanded if there was an enlargement of the pericholecystic space, and the space was bounded laterally by the edge of the right hepatic lobe, medially by the edge of the lateral segment of the left hepatic lobe and occasionally, posteriorly, by the anterior edge of the caudate lobe ${ }^{27}$. Thickening around the gallbladder or around the portal vein or its branches was considered if any tissue was interposed between the walls of these structures and the adjacent normal liver parenchyma. MRI scans were evaluated in groups of 10 exams, on a PACS (Picture Archiving and Communication System, Eastman Kodak Company, Rochester, New York, USA). Examiners knew that study patients had had a previous US showing hepatic involvement by schistosomiasis, and the US and MRI were performed without their having any knowledge of the results of the other imaging method. In two cases, evaluation of the gallbladder wall via imaging was not possible because of previous cholecystectomy.

\section{Statistical analysis}

Agreement between MRI readers was evaluated using kappa index. The degree of agreement ${ }^{28}$ was classified as follows: poor (0), slight ( 0.01 to 0.20$)$, fair ( 0.21 to 0.40$)$, moderate ( 0.41 to 0.60$)$, substantial ( 0.61 to 0.80$)$, or almost perfect ( 0.81 to 1.00$)$. In cases of disagreement, a consensus was to be reached.

\section{Ethical considerations}

The study protocol conformed to the ethical guidelines of the revised Helsinki Declaration (2000) and was approved by the research ethics board. All study subjects signed the informed consent before being enrolled.

\section{RESULTS}

Fifty-four patients (34 men and 20 women) were studied.

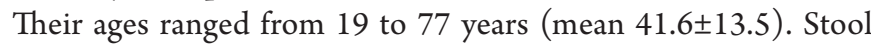
examination resulted positive for Schistosoma mansoni in 34 (63\%) of 54 patients, but 44 (81.5\%) patients reported previous treatment for schistosomiasis. Previous upper digestive bleeding was identified in $21(38.9 \%)$ patients, and 38 (70.4\%) patients had varices in upper digestive endoscopy. The liver and the spleen were palpable in 26 (48.1\%) patients. In 2 (3.7\%) patients, only the liver was evident on 
palpation, and in 19 (35.2\%), only the spleen. No previous history of surgery for portal hypertension, evidence of hepatic failure, hepatocyte destruction, toxic or viral hepatitis, or congestive heart failure was recorded.

Magnetic resonance imaging identified periportal thickening suggestive of schistosomal fibrosis in 47 (87\%) of the 54 cases. Thickening was detected around the portal vein bifurcation and secondary branches. MRI showed hypointense periportal bands on T1-weighted sequences (Figure 1), which were hyperintense in T2-weighted sequences, even after suppression of the fat tissue signal (Figure 2). Periportal thickening was enhanced after administration of gadolinium in 42 (89.4\%) of the 47 patients (Figure 1). Periportal enhancement in arterial, venous, and equilibrium phases were observed in $11.9 \%(5 / 42), 47.6 \%(20 / 42)$, and $100 \%(42 / 42)$ of the study subjects, respectively. In the 7 (13\%) of the 54 discordant cases, MRI revealed fat tissue filling in the hilar periportal space where US indicated isolated thickening around the main portal vein at the entry point into the liver (Figure 3). This was called the fatty hilum sign by the authors.
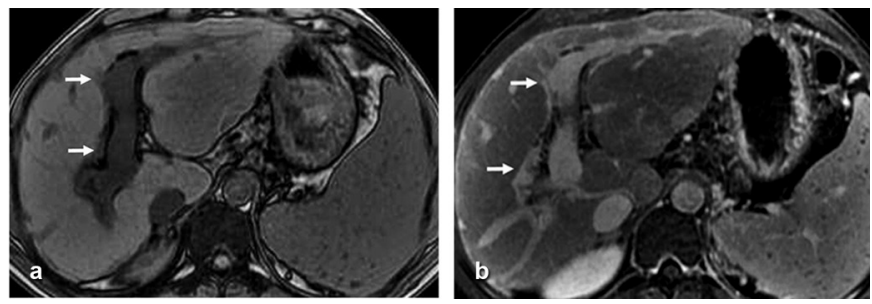

FIGURE 1 - a) Axial opposed-phase unenhanced T1-weighted gradient-echo MRI (TR/TE 150/2.1) shows periportal hypointense bands. b) Portal-phase contrastenhanced dynamic gradient-echo MRI (LAVA) shows periportal enhancement after intravenous administration of gadolinium suggesting periportal fibrosis.

MRI: magnetic resonance imaging; LAVA: liver acquisition with volume acceleration.
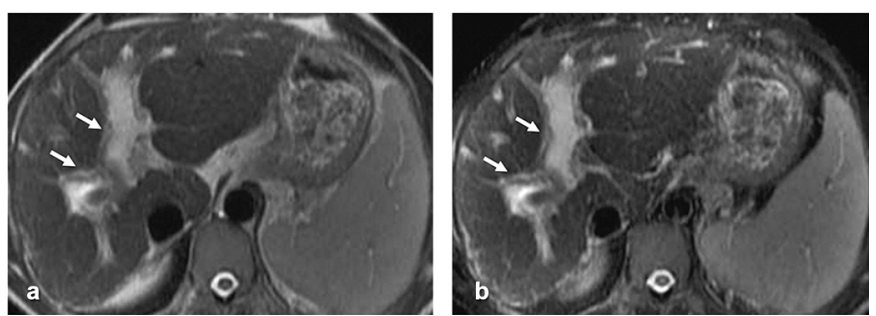

FIGURE 2 - a) Axial T2-weighted fast spin-echo MRI (1,800/90) reveals periportal hyperintense bands. b) Axial T2-weighted fast spin-echo MRI $(1,800 / 90)$ with fat suppression shows persisting hyperintense periportal bands. MRI: magnetic resonance imaging.
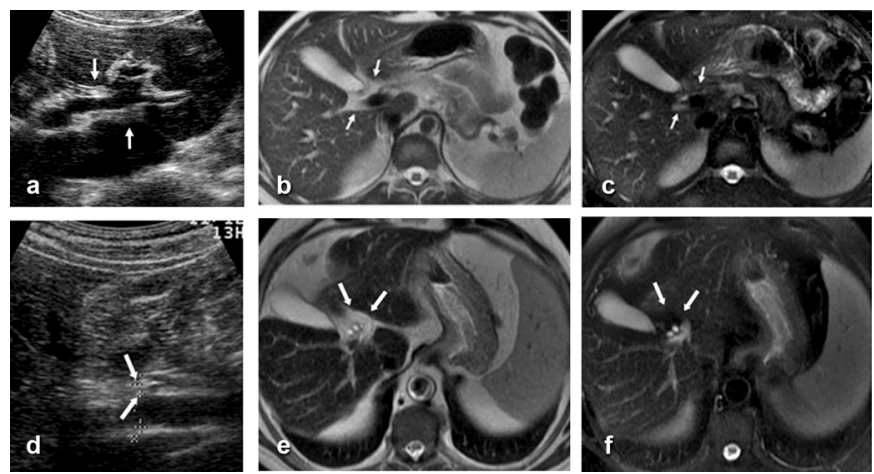

FIGURE 3 - a, d) US indicates isolated thickening around the portal vein the hilum, suggestive of schistosomal fibrosis but, in fact, representing a fatty hilum. b, e) Axial T2-weighted fast spin-echo MRI $(1,800 / 90)$ reveals hilar periportal hyperintense bands. c, f) Axial T2-weighted fast spin-echo MRI (1,800/90) with fat suppression shows that the central hyperintense periportal bands disappeared, corresponding to the fatty hilum.

US: ultrasound; MRI: magnetic resonance imaging.

Thirty-eight of the 47 patients with periportal thickening confirmed by MRI showed US-identified thickening of the main portal vein wall at the entry point to the liver. In 37 of 38 patients (in one, the main portal vein divided into the right and left branches immediately at entrance into the liver), MRI showed that thickening around the main portal vein in the hepatic hilum was fatty tissue.

Ultrasound identified thickening of the gallbladder wall in $48(92.3 \%)$ of the 52 cases of subjects that had not been submitted to cholecystectomy. One of the 47 patients with MRI evidence of periportal fibrosis had had his gallbladder removed. Thirty-five (76.1\%) of the other 46 patients had an expanded gallbladder fossa filled in with fat tissue (Figure 4). The remaining 11 (23.9\%) of 46 showed pericholecystic signs of fibrosis in MRI. Enhancement of pericholecystic fibrosis (Figure 5) was observed in 10 (90.9\%) of 11 patients. Enhancement in arterial, venous, and equilibrium phases were observed in $10 \%(1 / 10), 50 \%(5 / 10)$, and $100 \%(10 / 10)$ of the cases, respectively.

There was a perfect agreement (kappa index $=1.00$ ) between MRI readers concerning the identification of periportal thickening, pericholecystic thickening, fatty hilum, and expanded gallbladder fossa signs.
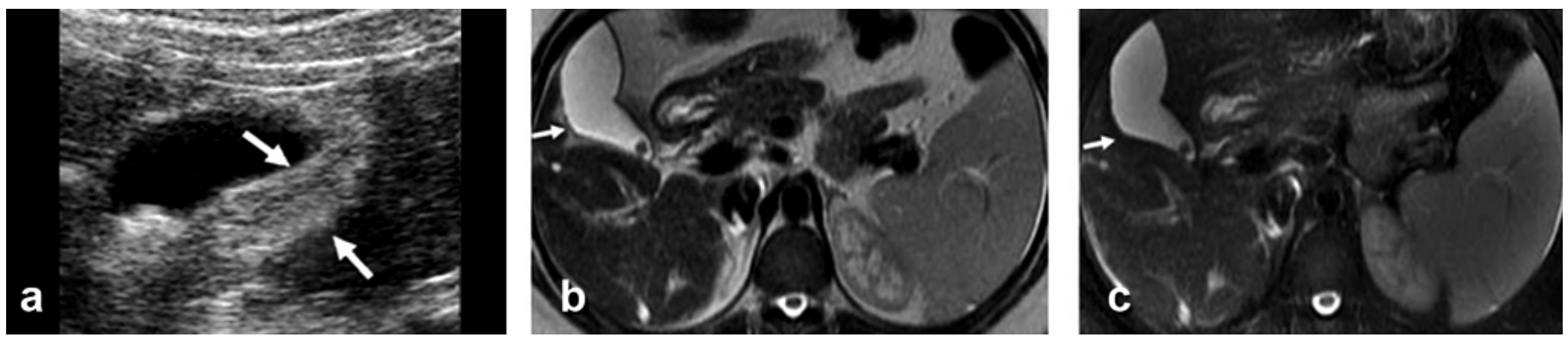

FIGURE 4 - a) US identifies thickening of the gallbladder wall, suggestive of schistosomal fibrosis but, in fact, representing an expanded gallbladder fossa filled with fatty tissue. b) Axial T2-weighted fast spin-echo MRI (1,800/90) shows pericholecystic hyperintense bands. c) Axial T2-weighted fast spin-echo MRI (1,800/90) with fat suppression shows that the pericholecystic bands disappeared, revealing an enlargement of the gallbladder fossa, which has been filled with adipose tissue. US: ultrasound; MRI: magnetic resonance imaging. 


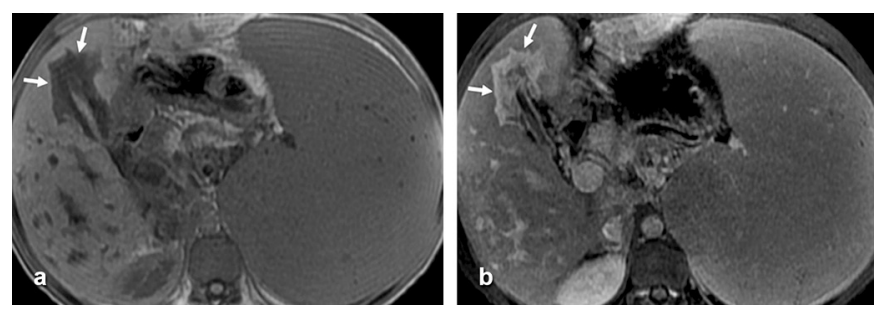

FIGURE 5 - a) In-phase unenhanced T1-weighted gradient-echo MRI (TR/TE 150/2.1) discloses pericholecystic hypointense bands, suggesting pericholecystic fibrosis. b) Portal-phase contrast-enhanced dynamic gradientecho MRI (LAVA) reveals pericholecystic enhancement.

MRI: magnetic resonance imaging; LAVA: liver acquisition with volume acceleration.

\section{DISCUSSION}

Ultrasound and MRI differed in diagnosing schistosomal liver fibrosis in 7 (13\%) of 54 cases. In these patients, MRI revealed fat tissue, whereas US indicated isolated hilar periportal thickening. There have been prior suggestions that central fibrosis was not a good marker of late stage schistosomiasis ${ }^{13}$. The pathology of hepatic disease in schistosomiasis suggests that there is a small probability of isolated central fibrosis occurring because the hepatic lesion begins in the periphery ${ }^{29,30}$. Ultrasound periportal thickening around the main portal vein in the hepatic hilum was shown to be fat tissue in MRI, even in the cases with confirmed fibrosis around the portal vein bifurcation and secondary branches. We called this phenomenon the fatty hilum sign.

In 35 (76.1\%) of 46 patients, pericholecystic thickening was actually fat tissue filling in the enlarged gallbladder fossa. Similar findings were described in patients with hepatic cirrhosis and referred to as the expanded gallbladder fossa sign ${ }^{27}$. This sign was assumed to be a specific indicator of cirrhosis, although the patients were compared only with the controls without liver disease. In the present study, the expanded gallbladder fossa sign also was found in patients with hepatosplenic schistosomiasis. Ultrasound-diagnosed gallbladder wall thickening has been used in schistosomiasis to indicate the intensity of liver fibrosis and irreversibility of hepatic involvement after treatment ${ }^{31}$. Although not indicative of fibrosis in all cases, but of an enlarged gallbladder fossa, pericholecystic thickening in US findings may actually be a good marker for advanced liver schistosomal disease. The expanded pericholecystic space can be explained by combined hepatic morphological alterations, which produce the caudate lobe hypertrophy and the right lobe atrophy usually described in schistosomiasis.

Enhancement of the periportal tissue after contrast injection may be attributed to inflammation, to the sheath of dilated vessels in the wall of the portal vein or to fibrosis. Leakage of gadolinium from the intravascular into the interstitial space and reduced washout of contrast within the fibrotic areas could be responsible for progressive enhancement in portal venous and equilibrium phase images ${ }^{20}$. Enhancement in the arterial phase in $11.9 \%$ of our patients may be due to acute inflammation or to a compensatory increase in hepatic arterial flow because of portal hypertension ${ }^{32,33}$. The lack of contrast enhancement of periportal tissue in $5(10.6 \%)$ of 47 cases may represent advanced stages of fibrosis; longer image acquisition delay may reveal enhancement ${ }^{25}$.

This study was not designed to define the accuracy of the imaging methods in diagnosing hepatic involvement in schistosomiasis.
The gold-standard procedure in evaluating schistosomal hepatic fibrosis - wedge liver biopsy-is an invasive procedure and not justified for this group of patients. Because the ability of MRI to identify fat tissue is well established, we relied on it to exclude central periportal fibrosis in the seven discordant cases.

There is no definite algorithm for evaluating schistosomiasisrelated morbidity. The association of comprehensive history and physical examination, basic laboratory tests (stool examination for S. mansoni eggs and blood cell count), and imaging methods seem to offer the best approach in evaluating patients with this disease. For the time being, MRI's costs are restricting, which prevent it from being used in field-based studies or routinely in developing countries. Ultrasound will likely continue to be the imaging method of choice to evaluate liver involvement in schistosomiasis. However, in cases where research is involved or in special cases where US fails to establish a diagnosis or reveals isolated hilar thickening around the main portal vein, MRI seems to be a wise choice.

In conclusion, MRI confirmed the presence of periportal fibrosis described in ultrasound findings in schistosomiasis in most (87\%) of our cases. However, in a given group of patients, pericholecystic and hilar periportal thickening was not fibrous tissue but fat tissue filling in an empty space. The finding of fat tissue filling in an expanded gallbladder fossa does not change the interpretation of the liver disease. In fact, patients with pericholecystic fibrosis or fat may have equally severe hepatic involvement. The mechanisms and implications of the expansion of the gallbladder fossa deserve further investigation, as this expansion is probably because of morphological changes in the liver in schistosomiasis.

\section{CONFLICT OF INTEREST}

The authors declare that there is no conflict of interest.

\section{FINANCIAL SUPPORT}

This study was partially financed by Conselho Nacional de Desenvolvimento Científico e Tecnológico (CNPq) and Coordenação de Aperfeiçoamento de Pessoal de Nível Superior (CAPES).

\section{REFERENCES}

1. Lambertucci JR. Schistosoma mansoni: pathological and clinical aspects In: Jordan P, Webbe G, editors. Human Schistosomiasis. $3^{\text {rd }}$ ed. Wallingford: Cab International; 1993. p. 195-235.

2. Lambertucci JR, Serufo JC, Gerspacher-Lara R, Rayes AAM, Teixeira R, Nobre $\mathrm{V}$, et al. Schistosoma mansoni: assessment of morbidity before and after control. Acta Trop 2000; 77:101-109.

3. Bogliolo L. The anatomical picture of the liver in hepato-splenic schistosomiasis mansoni. Ann Trop Med Parasitol 1957; 51:1-14.

4. Cheever AW. A quantitative post mortem study of schistosomiasis mansoni in man. Am J Trop Med Hyg 1968; 17:38-64.

5. Maharaj B, Maharaj RJ, Leary WP, Cooppan RM, Naran AD, Pirie D, et al Sampling variability and its influence on the diagnostic yield of percutaneous needle biopsy of the liver. Lancet 1986; 1:523-525.

6. Lambertucci JR, Gerspacher-Lara R, Pinto-Silva RA, Barbosa MM, Teixeira R, Barbosa HF, et al. The Queixadinha Project: morbidity and control of schistosomiasis in an endemic area in the northeast of Minas Gerais, Brazil. Rev Soc Bras Med Trop 1996; 29:127-135.

7. Richter J, Domingues ALC, Barata CH, Prata AR, Lambertucci JR. Report on the second satellite symposium on ultrasound in schistosomiasis. Mem Inst Oswaldo Cruz 2001; 96 (supl):151-156. 
8. Abdel-Latif Z, Abdel-Wahab MF, El-Kady NM. Evaluation of portal hypertension in cases of hepatosplenic schistosomiasis using ultrasound. J Clin Ultrasound $1981 ; 9: 409-412$

9. Cerri GG, Alves VA, Magalhães A. Hepatosplenic schistosomiasis mansoni: ultrasound manifestations. Radiology 1984; 153:777-780.

10. Homeida M, Abdel-Gadir AF, Cheever AW, Bennett JL, Arbab BMO, Ibrahim SZ, et al. Diagnosis of pathologically confirmed Symmers' periportal fibrosis by ultrasonography: a propspective blinded study. Am J Trop Med Hyg 1988; 38:86-91.

11. Abdel-Wahab MF, Esmat G, Milad M, Abdel-Razek S, Strickland GT. Characteristic sonographic pattern of schistosomal hepatic fibrosis. Am J Trop Med Hyg 1989; 40:72-76.

12. Pinto-Silva RA, Abrantes WL, Antunes CM, Lambertucci JR. Sonographic features of portal hypertension in schistosomiasis mansoni. Rev Inst Med Trop São Paulo 1994; 36:355-361.

13. Gerspacher-Lara R, Pinto-Silva RA, Serufo JC, Rayes AAM, Drummond SC, Lambertucci JR. Splenic palpation for the evaluation of morbidity due to schistosomiasis mansoni. Mem Inst Oswaldo Cruz 1998; 93(supl 1):245-248.

14. Richter J, Hatz C, Campagne G, Bergquist NR, Jenkins JM. Ultrasound in schistosomiasis. A practical guide to the standardized use of ultrasonography for the assessment of schistosomiasis-related morbidity [Internet]. Niamey, Niger: WHO; 2000. [Cited 2011 August 29]. 49 p. Available from: http:// apps.who.int/tdr/publications/training-guideline-publications/ultrasound-inschistosomiasis/pdf/ultrasound-schistosomiasis.pdf/.

15. Lambertucci JR, Cota GF, Pinto-Silva RA, Serufo JC, Gerspacher-Lara R, Drummond CS, et al. Hepatosplenic schistosomiasis in field-bases studies: a combined clinical and sonografic definition. Mem Inst Oswaldo Cruz 2001; 96 (supl):147-150.

16. LambertucciJR, Silva LCS, Andrade LM, Queiroz LC, Carvalho VT, Voieta I, et al. Imaging techniques in the evaluation of morbidity in schistosomiasis mansoni. Acta Trop 2008; 108:209-217.

17. Lambertucci JR, Pinto-Silva RA, Gerspacher-Lara R, Barata CH. Acute Manson's schistosomiasis: sonographic features. Trans R Soc Trop Med Hyg 1994; 88:7677.

18. Barata CH, Pinto-Silva RA, Lambertucci JR. Abdominal ultrasound in acute schistosomiasis mansoni. Br J Radiol 1999; 72:949-952.

19. Patel AS, Castillo DF, Hibbeln JF, Watkins JL. Magnetic resonance imaging appearance of hepatic schistosomiasis, with ultrasound and computed tomography correlation. Am J Gastroenterol 1993; 88:113-116.
20. Willemsen UF, Pfluger TH, Zoller WG, Kueffer G, Hahn K. MRI of hepatic schistosomiasis mansoni. J Comput Assit Tomogr 1995; 19:811-813.

21. Lambertucci JR, Andrade LM, Pinto-Silva RA. Magnetic resonance imaging of the liver in hepatosplenic schistosomiasis mansoni. Rev Soc Bras Med Trop 2002; 35:679-680.

22. Lambertucci JR, Silva LCS, Andrade LM, Queiroz LC, Pinto-Silva RA. Magnetic resonance imaging and ultrasound in hepatosplenic schistosomiasis mansoni. Rev Soc Bras Med Trop 2004; 37:333-337.

23. Bezerra ASA, D’ Ippolito G, Caldana RP, Cecin AO, Szejnfeld J. Avaliação hepática e esplênica por ressonância magnética em pacientes portadores de esquistossomose mansônica crônica. Radiol Bras 2004; 37:313-321.

24. Silva LCS, Pereira ACF, Queiroz LC, Andrade LM, Antunes CMF, Lambertucci JR. Disagreement between ultrasound and magnetic resonance imaging in the identification of schistosomal periportal fibrosis. Mem Inst Oswaldo Cruz 2006; 101(supl 1):279-282.

25. Bezerra ASA, D’ Ippolito G, Caldana RP, Cecin AO, Ahmed M, Szejnfeld J. Chronic hepatosplenic schistosomiasis mansoni: magnetic resonance imaging and magnetic resonance angiography findings. Acta Radiol 2007; 48:125-134.

26. Bezerra ASA, D' Ippolito G, Caldana RP, Leoploldino DD, Batista GR, Borges DR, et al. Differentiating cirrhosis and chronic hepatosplenic schistosomiasis using MRI. Am J Roentgenol 2008; 190:W201-207.

27. Ito K, Mitchell DG, Gabata T, Hussain SM. Expanded gallbladder fossa: simple MRI imaging sign of cirrhosis. Radiology 1999; 211:723-726.

28. Landis JR, Koch GG. The measurement of observer agreement for categorical data. Biometrics 1977; 33:159-174.

29. Andrade ZA, Cheever AW. Alterations of the intrahepatic vasculature in hepatosplenic schistosomiasis mansoni. Am J Trop Med Hyg 1971; 20:425-432.

30. Andrade ZA. Schistosomal hepatopathy. Mem Inst Oswaldo Cruz 2004; 99 (supl 1):51-57.

31. Cota GF, Pinto-Silva RA, Antunes CMF, Lambertucci JR. Ultrasound and clinical investigation of hepatosplenic schistosomiasis: evaluation of splenomegaly and liver fibrosis four years after mass chemotherapy with oxamniquine. Am J Trop Med Hyg 2006; 74:103-107.

32. Fataar S, Bassiony H, Satyanath S, Rudwan MA, Khaffaji S, El Magdy W, et al. CT of hepatic schistosomiasis mansoni. Am J Roentgenol 1985; 145:63-66.

33. Vitellas KM, Tzalonikou MT, Bennett WF, Vaswani KK, Bova JG. Cirrhosis: spectrum of findings on unenhanced and dynamic gadolinium-enhanced MR imaging. Abdom imaging 2001; 26:601-615. 